\title{
Built Heritage Attractions in Cultural Tourism: the case of Al - Mustansiriya Madrassa, Baghdad
}

\author{
Huda Adil Al-Obaidi ${ }^{*}$, Osamah AbdulMunem Al-Tameemi ${ }^{2}$
}

\section{Authors affiliations:}

1*) M.Sc. student, Architecture Engineering Dep., University of Baghdad, Baghdad, Iraq. dolaarch@yahoo.com

2) Architecture Engineering Dep., University of Baghdad, Baghdad, Iraq.

eng usama oat@yahoo.com

\section{Paper History:}

Received: $25^{\text {th }}$ Nov. 2018

Revised: $18^{\text {th }}$ Dec. 2018

Accepted: $18^{\text {th }}$ March. 2019

\begin{abstract}
This research deals with the subject of Built heritage attractions in Muslim historical building, for what it represents, as an element dealing with Cultural tourism, in the process of developing tourism industry of the city.

The location of Mustansiriya Madrassa in Baghdad's commercial district could make it a profitable investment project to revive a cultural, artistic and tourist centre that could make it a cultural Tourism haven.

The problem emerges through, how the role of built heritage to attract tourists in order to give vitality and liveability to the cultural tourism destination such as $\mathrm{Al}$ - Mustansiriya Madrassa which is one of the most popular heritage destinations, a historic school building situated in the ancient Abbasid district of Rusafa in the very heart of Baghdad.

Therefore, the research's aim is to shed light on the heritage attraction as a mean to clarify the meaning of Cultural Tourism and specifying its definition.

This research explains how the built heritage plays an important role in tourism in general and in the cultural tourism in particular because they attract tourists and provides a sustainable economic resource through its inclusion of values that make it distinct from other sources of attraction.
\end{abstract}

Keywords: Built Heritage, Attractions, Mustansiriya Madrassa, Baghdad, Cultural Tourism.

$$
\begin{aligned}
& \text { جاذبية التراث المبني في السياحة الثقافية : المدرسة المستنصرية كحالة دراسية } \\
& \text { هدى عادل العبيدي" ، ، اسامة عبد المنعم التميمي } 2 \\
& \text { الخلاصة: } \\
& \text { يتناول هذا البحث موضوع جاذبية التزاث المبني لمبنى تاريخي اسلايي، لما يمثله كنصر يتعامل مع السياحة } \\
& \text { الثقافية في عملية تطوير صناعة السياحة في المدينة. }
\end{aligned}
$$

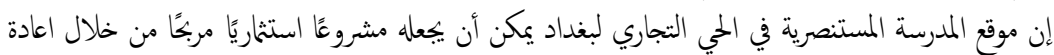

$$
\begin{aligned}
& \text { احياء مركز ثقافي وفني وسياحي يمكن أن يخلق منه ملاذًا سياحيًا ثقافيًا. }
\end{aligned}
$$

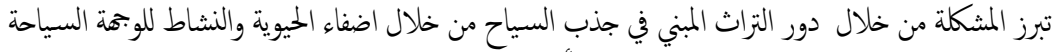

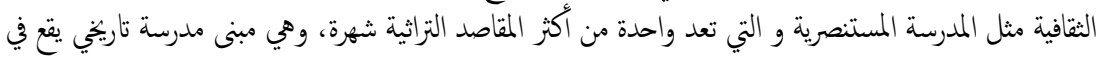

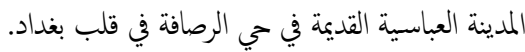

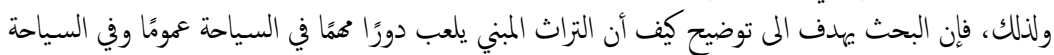

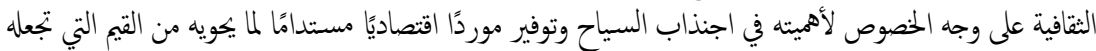

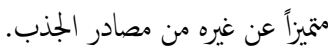

$$
\begin{aligned}
& \text { الكلمات المثتاحية: التزاث المبني ، المعالم ، المدرسة المستنصرية ، بغداد ، السياحة الثقافية. }
\end{aligned}
$$

\section{Introduction:}

Heritage' and 'Culture' have become Linked and flexible terms. Cultural tourism is a recently "fashionable" phenomenon. Views are different according to what belongs to this idea; some focus only on cultural values for example the study of Polácek and Aroch (1984), and some others classify natural values as well like the study of Gunn (1972), and some of the World

Heritage have unique monument among them. Heritage attractions enchant a wide range of tourists, including those with particular interests in history and heritage besides those who have a less defined concern but may be instigated by directions with identity. Heritage attractions in the global era offer incomeproducing chances to tourists, communities, but the tourism that follows has caused the demolition of traditional buildings and historic spaces.

\section{Cultural Tourism:}

Culture is a tourist destination with a traditional character, a liveable present and a vivid future. In the twentieth century, nevertheless, culture has stopped to be the target of tourism: tourism is culture. [1]. 
There are several definitions of cultural tourism in use, Stebbins (1996) states that "Cultural tourism is a brand of particular concern tourism based on the seeking for and harmony in new and profound cultural experiences, whether aesthetic, intellectual, emotional, or psychological." [2].

ICOMOS (International Scientific Committee on Cultural Tourism) (1990) defined Cultural tourism as: "The process through which the tourist can experience the lifestyle of others and understand their traditions and customs, as well as to identify the physical environment which is embodied through architectural buildings, historical sites, cultural monuments and other artifacts of the previous time. [3]

Australian Office of National Tourism defined cultural tourism as: "tourism that specialized in studying the culture of a destination which includes the life pattern, arts, heritage, industries and leisure of the local population". [4]

Cultural tourism also can be defined as "the phenomenon of people moving from place to another with the intention of either testing another culture or the cultural attractions of a specific destination". [5]

The report of the European Travel Commission on City Tourism and Culture (2005) characterize inward and outward circles of cultural tourism:

1- The inward circle discusses the essential components of tourism which can be separated into two sections: heritage tourism which include social traditions and an ancient iconic building of the past and expressions tourism which is identified with contemporary social generation, for example, the performing and visual arts, contemporary design, writing, and et.

2- The outward circle discusses the auxiliary components of tourism which can be separated into two components, to be specific way of life (components, for example, convictions, food, legends, and so on) and the imaginative ventures (form configuration, web and visual communication, film, media and stimulation, etc.). [6].

According to the ATLAS program there are two new definitions for cultural tourism from a specialized point of view:

\section{Conceptual Definition:}

"The movement of people away from their home place to a cultural destination, in order to fulfil their cultural needs, by gathering new information and experiences".

\section{Technical Definition:}

"All movements of people to specific cultural destination, such as artistic and cultural manifestations, heritage sites, arts and drama outside their home place". [7].

In economic terms, cultural tourism can be defined as "a product or an industry in which the element of supply is represented by the recognition of a new culture, participation in cultural events or visits to cultural attractions. The demand element is the culture of the destination". [8]

\section{Tourism Attraction:}

Tourism attractions are one of the fundamental ingredients of the tourism, in addition they are usually the motivating factor to visit specific destinations or places. Attraction is "the force or activity of attracting, or an eligible or enjoyable quality or thing". [9].

"without tourist attractions there would be no tourism. [10]. Without tourism there would be no tourist attractions". [11].

Gunn (1972) defined an attraction as being magnetic; and he indicated that "sometimes natural and historic features have intrinsic attracting power". [12]

The attraction model of Gunn (1988) as three circles:

- The central circle (nucleus): the major source of attracting tourists which includes natural or cultural heritage site.

- The middle circle is the protector zone, which conducts as coordinator of the tourism movement.

- The outer circle of the model is the territory embracing the attractions. It includes tourist services, such as feeding, retail, accommodation, transportation services, amusement and inquiry. [9]

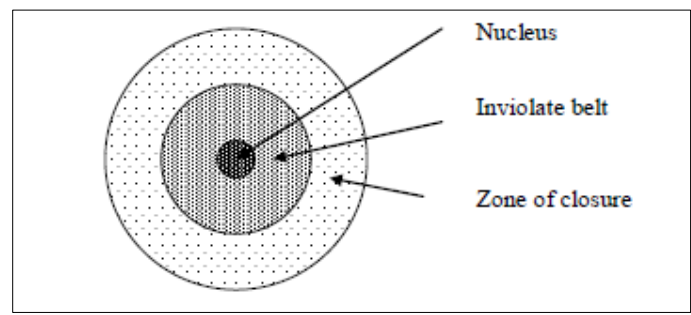

Diagram.1 Model of tourist attraction (Gunn, 1988)

According to Walsh-Heron \& Stevens (1990), a tourism attraction "is a distinctive element in a place that is a venue, or centre of interests and does the following: attract tourists, and give them a pleasant and unforgettable experience. [13].

Leiper (2004) adapted MacCannell's (1999) tourist attraction model and discussed the concept of a primary, secondary and tertiary attraction. A primary attraction influences a tourist or human element. The second one is a core (sight in MacCannell's model) or focal component, an element or trademark that is thought about before visiting a place. A tertiary one is a marker or useful component; something obscure pre-visit, however found by a guest. furthermore, $\mathrm{He}$ expressed that cores can go from bigger spaces to smaller ones, for example, nation, area, region, city, town, site, building, and individual rooms.

The psychologist P. Pearce (1991), proposed another precise definition: "A specific place with a special label, features (natural or man-made) and specific people, which has the ability to attract tourists and management". [14].

P. Kotler (1994) applied the attractions product model which identifies three levels of a product:

- $\quad$ The core product
- $\quad$ The tangible product
- $\quad$ The augmented product. [15] 


\section{Tourism Attraction Typologies:}

There are different types of tourism attraction, which can be considered as the reason why tourists and excursionists visit a tourism destination and, as such, are considered basic tourism resources.

Tourist attractions can be assembled into those, which are common, and those, which have been developed. [15].

Polácek and Aroch (1984) produced a typology of tourist attractions with seven classifications of attraction identified, three were principally cultural:

- Cultural and verifiable landmarks.

- Artistic and social indications.

- Traditional occasions.

- The great attractions of social tourism can be ordered into three gatherings:

- Built and material esteems (structures, material estimations of various works of art),

- The social esteems associated with regular day to day existence (available time, recreation, the way of life, propensities, gastronomy)

- Events and celebrations. [16].

A. Lew (1987) identifies three broad views of the classification of tourism attractions: ideological, hierarchical point of view and psychological approach. The ideological perspective focuses on the unique features typical of the site. The hierarchical/formative point of view accentuates the land and transient parts of the fascination, and its ability, while the subjective viewpoint considers the impression of guests and their encounters got from vacation spots. [11].

A few authors have recommended separating them into 'asset-based' and 'client-based' or 'reproducible' and 'non-reproducible'

There are four main types of attractions:

1. Highlights inside the indigenous habitat.

2. Human-made structures, structures, and locales that were intended for a reason other than drawing in guests, for example, religious love, yet which now pull in generous quantities of guests who utilize them as recreation luxuries.

3. Human-made structures, structures, and locales that are intended to draw in guests and are reason worked to suit their necessities, for example, amusement parks.

4. Extraordinary occasions.

Another typology of attractions that are based on: (i) natural features; (ii) man-made features; (iii) cultural features; or (iv) the combination of these three, which dependent on:

- the nature, size and area of attractions

- developed, common, or seasonal event. [15].

\section{Built Heritage Attraction:}

The appellation 'heritage' is often vaguely defined, and refer to various things to various people. Heritage is connected with the past, that it represents kind of inheritance to be passed down to present and future generations, both in terms of cultural traditions and physical artefact". [17].

The term heritage began to enter tourism in a clear manner in 1970, but it has been linked to tourism since previous times. The religious festivals that were held in both the Babylonian and Egyptian civilizations attracted visitors to see the famous buildings and landmarks of the cities as well as attracting the agog worshipper. [18].

Heritage resources sectioned into tangible and intangible resources. Tangible resources include: environmental (natural) and cultural heritage. Cultural heritage includes man-made objects, such as sculpture and painting, monuments of architecture, sites of human work, building complexes as well as cultural landscapes and historical sites scientific, environmental or aesthetic value. [19].

The linkage between tourism and heritage sites is dynamic and may embrace value discrepancies. Thus, the heritage places must be organized sustainably to maintain them for current and future generations. [20].

Nowadays, historical buildings as a part of cultural heritage have become an important tourism product, therefore many destinations have funded and supported their renewal and reuse.

Conservation of built heritage is a human responsibility that contributes to preserving the features of the past for future generations. This architectural heritage is a major attraction for cultural tourists interested in history as it represents the vivid embodiment of the history and the development of human thought among different civilizations because their values, which can be summed up as:

- Historical value, the city, and its archaeological buildings had scientific values reflect a certain era or a certain event in the history of mankind.

- Artistic value, which is the value that expresses one of the characteristics of the heritage building (elements, patterns, style, ....).

- Practical value, which is represented by its architectural legacies which are still used today, or at least can be restored, employ to play a role in people's lives and to become a tourist attraction. [21].

Built heritage attractions supply a range of pleasant and leisure experiences, in addition, they include various events that act as an economic resource for the country, and a focus for community identity because of their symbols, methods, sources for education and values. Thus, they are multipurpose. [22].

It is clear from the above that the built heritage plays a major role in supporting tourism in general and cultural tourism in particular through:

- It is a major source of attraction for local and foreign tourists and their different interests (historical, cultural, artistic, architectural, religious).

- Is a major source of income through its investment for tourism purposes commensurate with (location, function, historical importance, construction status, economic situation, community awareness) making it a sustainable source of income.

This indicates the many values possessed by the heritage in general and the built heritage in particular, which can be explained by the following table:

Table (1): studies of tourism attraction and heritage values induced by it: 


\begin{tabular}{|c|c|c|}
\hline $\begin{array}{l}\text { The source } \\
\text { of the study } \\
\text { of tourism } \\
\text { attraction }\end{array}$ & $\begin{array}{l}\text { The description } \\
\text { of the study }\end{array}$ & $\begin{array}{l}\text { Heritage value } \\
\text { induced by the } \\
\text { study }\end{array}$ \\
\hline $\begin{array}{l}\text { Nowacki, M.( } \\
\text { 2013) }\end{array}$ & the quality & authenticity value \\
\hline $\begin{array}{l}\text { Hassan } \\
(2005)\end{array}$ & $\begin{array}{l}\text { historic features } \\
\text { and expresse one } \\
\text { of the } \\
\text { characteristics } \\
\text { and architectural } \\
\text { legacies, employ } \\
\text { to play a role in } \\
\text { people's lives }\end{array}$ & $\begin{array}{l}\text { historical and } \\
\text { scientific and } \\
\text { artistic and } \\
\text { practical value }\end{array}$ \\
\hline Leiper (2004) & $\begin{array}{l}\text { tourist or human } \\
\text { element sight or } \\
\text { focal component } \\
\text { marker or useful } \\
\text { component }\end{array}$ & $\begin{array}{l}\text { social, } \\
\text { geographical, and } \\
\text { economical value }\end{array}$ \\
\hline Kotler (1994) & $\begin{array}{l}\text { attraction } \\
\text { products: the } \\
\text { core product } \\
\text { (benefits, } \\
\text { experiences, } \\
\text { leisure), the } \\
\text { tangible product } \\
\text { (exhibitions, } \\
\text { forms of activity, } \\
\text { security) and the } \\
\text { augmented } \\
\text { product (catering } \\
\text { services, stores, } \\
\text { opening time). }\end{array}$ & $\begin{array}{l}\text { social, historical, } \\
\text { aesthetic and } \\
\text { economical value }\end{array}$ \\
\hline $\begin{array}{l}\text { P. Pearce } \\
(1991)\end{array}$ & $\begin{array}{ll}\text { site with natural } \\
\text { and } & \text { human } \\
\text { features } & \\
\end{array}$ & $\begin{array}{l}\text { historical and } \\
\text { aesthetic value }\end{array}$ \\
\hline 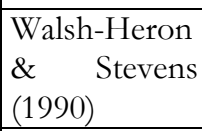 & $\begin{array}{l}\text { a fun and } \\
\text { pleasurable } \\
\text { experience }\end{array}$ & social value \\
\hline $\begin{array}{l}\text { Polácek and } \\
\text { Aroch (1984) }\end{array}$ & $\begin{array}{l}\text { cultural } \\
\text { landmarks and } \\
\text { artistic, social } \\
\text { indications and } \\
\text { material } \\
\text { structures, } \\
\text { material } \\
\text { estimations of } \\
\text { various works }\end{array}$ & $\begin{array}{lr}\text { cultural , artistic, } \\
\text { social and } \\
\text { architectural value }\end{array}$ \\
\hline $\begin{array}{l}\text { Gunn } \\
(1972)\end{array}$ & $\begin{array}{l}\text { natural and } \\
\text { historic features }\end{array}$ & $\begin{array}{l}\text { historical, aesthetic } \\
\text { and geographical } \\
\text { value }\end{array}$ \\
\hline
\end{tabular}

\section{Case Study: Mustansiriya Madrassa}

The built heritage attraction selected for the present research is Mustansiriya Madrassa a building of considerable historical and architectural importance. The building is an important catalyst for cultural tourism growth for a variety of reasons, which will be identified through S.O.W.T analysis. for assessing the touristic importance of Mustansiriya Madrassa as a built heritage attraction by described its heritage values.

\subsection{Description:}

Mustansiriya Madrassa (Arabic,المدرسة المستنصرية) is a historical building in Baghdad, Iraq, set up by the Abbasid Caliph Al-Mustansir Bi'llah. The building survived from the Mongol attack of 1258, and has been re-established. [23].

\section{- The Building Location:}

It is situated on the eastern bank of the Tigris, near Rashid Street, and the Shuhada' Bridge, close-by structures incorporated the Saray souq, the Baghdadi Gallery, Mutanabbi Road, the Abbasid Royal residence and Caliph's Road. [23]. This was the focal point of the historic urban fabric, where the spines coming from the eastern gates of $\mathrm{Bab}$ al- Thalassa and $\mathrm{Bab}$ alWastani converged. It was accessible from the Tigris, which functioned as the main transportation axis of the city, from where a pontoon bridge provided a direct connection with the al-Karkh quarter on the other side of the river. [24]

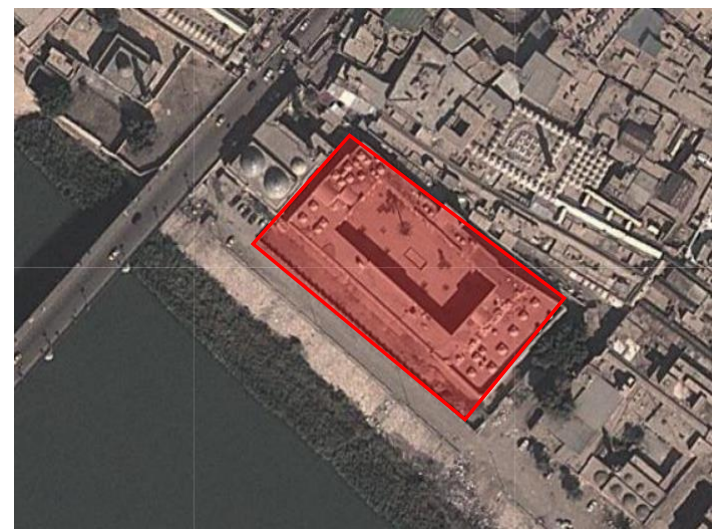

Figure (1): Mustansiriya Madrassa location.

(https://virtualglobetrotting.com/map/mustansiriyamadrasah/view/google/)

\section{- The Building Usage:}

- Set up in 1227/625 AH as a first theological madrassa in which all four madhabs (rites) of Islamic law were taught. Also includes a library, a hospital, and a pharmacy.

- 1750/1163 AH the craftsmen occupied the building.

- in 1865, the madrasa was converted to a customs office under the Ottomans.

- By 1945, the Iraqi Directorate of Antiquities had initiated a campaign to restore this historic monument and cleared the surrounding area from shops and structures.

- In 1960, the restored madrasa became a museum for Islamic art and culture (The Museum of Islamic Art in Baghdad) [25]

\section{- The Building Form:}

The building is rectangular, and two storeys high, with a large courtyard, in the middle. The huge building, measuring $106 \times 48$ meters, has three iwans on the North, West and East sides, connected by halls and smaller rooms. There are while in the middle of 
the South iwan is situated the mosque. The North "iwan" is used as the entrance passage. The main entrance is a monumental portal that projects from the façade of the building's north-eastern side. [26].

All around the courtyard and the upper storey are rooms for different usages. Those in the upper storey could be student's dwellings'-rooms. The decoration is completely modern, but mostly according to the previous patterns of which were found some remains before the restoration works began. [23]. Figure 2-3.

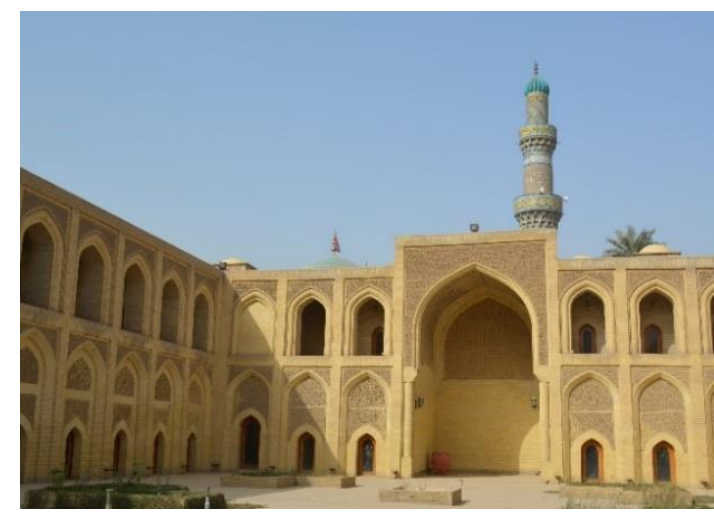

Figure (2): Mustansiriya Madrassa courtyard (Authors, 2018)

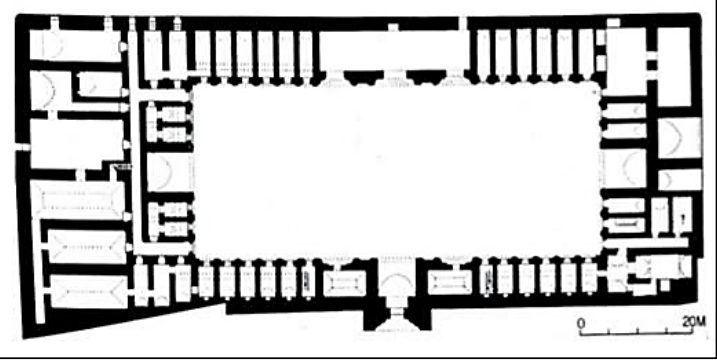

Figure (3): Mustansiriya Madrassa plan. (https://www.pinterest.com/pin/6080563871626559 $90 / ? \operatorname{lp}=$ true $)$

\subsection{Tourism importance of Mustansiriya Madrasah:}

The importance of expanding the cultural area by adding the building of Mustansiriya Madrassa to the Iraqi cultural scene, which began to expand and takes other dimensions in the atmosphere of openness and enjoyment of freedoms and this requires the joint efforts between the Ministries of Tourism, Antiquities, Culture and the Mayoralty of Baghdad.

The nature of the Mustansiriya Madrassa, the Islamic architectural style, the scientific importance it plays as it is one of the oldest universities in the world and its functioning role in the present day society in the region, all these making it the focus of attention of both foreign and local tourists and as a result an important cultural destination and, put it in the centre of the lights again.

Table (2): SWOT analysis for assessing the attraction of Mustansiriya Madrassa.

\begin{tabular}{|l|}
\hline Strengths: \\
\hline - it is an ancient school founded in 1233 (Abbasid \\
time)( historical value)
\end{tabular}

- The cultural importance of the building as a dedicated study of various sciences. (cultural and scientific value)

- The symbolism of the building is represented by elements and architectural details such as (Patterning and Islamic arches). Figure 4-5. (artistic and architectural value)

- The privileged location which overlooking the Tigris River directly. (geographical value)

- The historic urban fabric surrounding the building. (historical value)

- Accessible from the Tigris.

\section{Weakness:}

- Inadequacy of traditional economic activities which contribute to the activation of the building. (economical value)

- Lack of clarity of the building entrance (difficult access). Figure 6.( practical value)

- Lack of social awareness towards activating the touring side. Figure7.( social value)

\section{Opportunities:}

- The distinctive urban context that offers high attraction possibilities. (geographical value)

- Rehabilitation of materials and components using conservation levels.(structural value)

- To take advantage of the design elements in terms of proportions and details by introducing advanced techniques to make them attractive elements. (artistic value)

- The possibility of providing economic resources through the influx of tourists and other activities. Figure 8. (economical value).

\section{Threats:}

- Neglect for long periods of time.

- Lack of clear government programs to promote the building through the development of sustainable development plans. Figure 9. (social and cultural value)

- Environmental degradation factors that affected the elements, materials, and details.

- River edge problems that directly affect the structure of the building and its visible elements. Figure10.

- Exposure to fires. Figure11-12. (structural value)

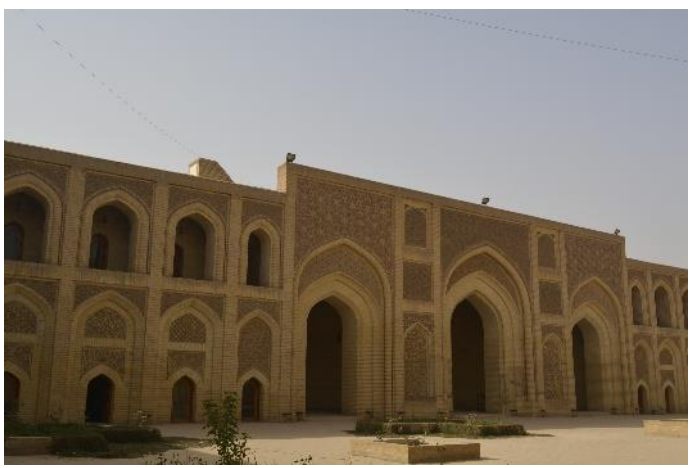

Figure (4): Mustansiriya arches pattern (Authors, 2018) 


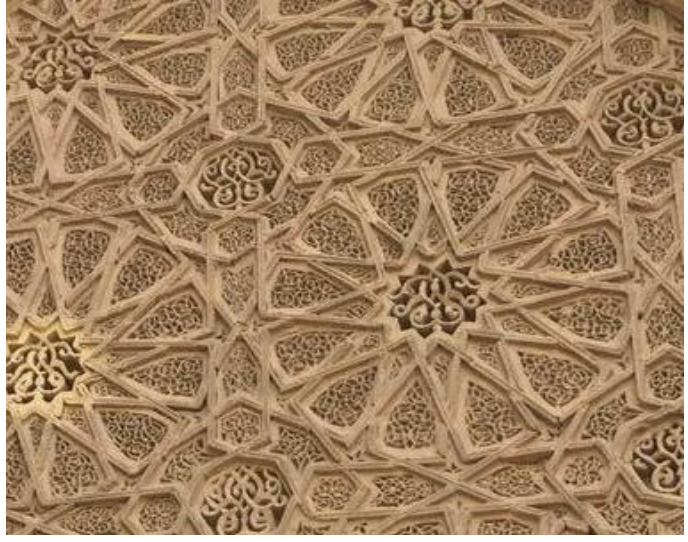

Figure (5): Mustansiriya ornaments (Authors, 2018)

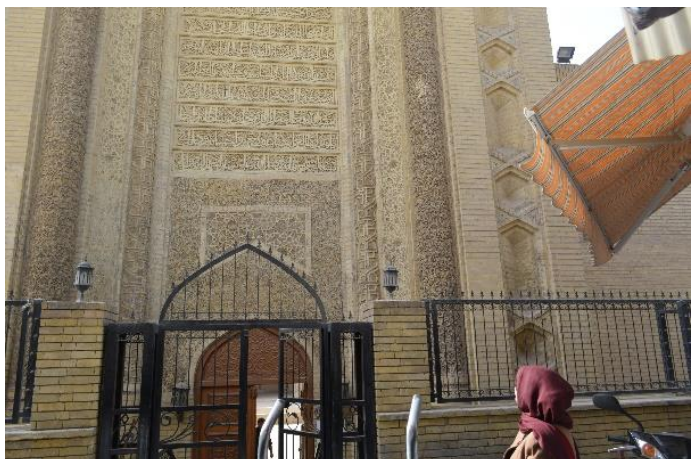

Figure (6): Mustansiriya entrance (Authors, 2018)

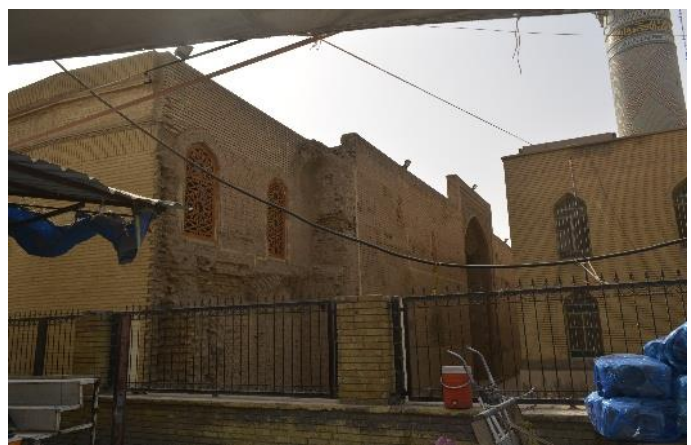

Figure (7): Mustansiriya missing parts (Authors, 2018)

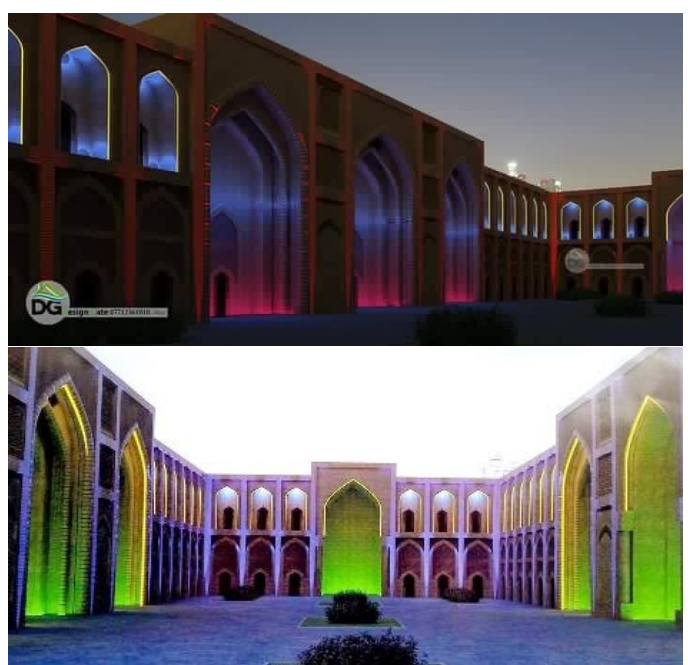

Figure (8): Mustansiriya light technology (https://zenabayar.wordpress.com, 2015)

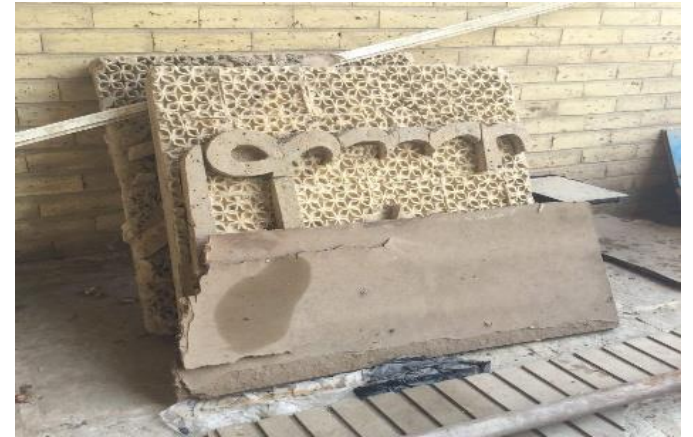

Figure (9): Mustansiriya restoration (Authors, 2018)

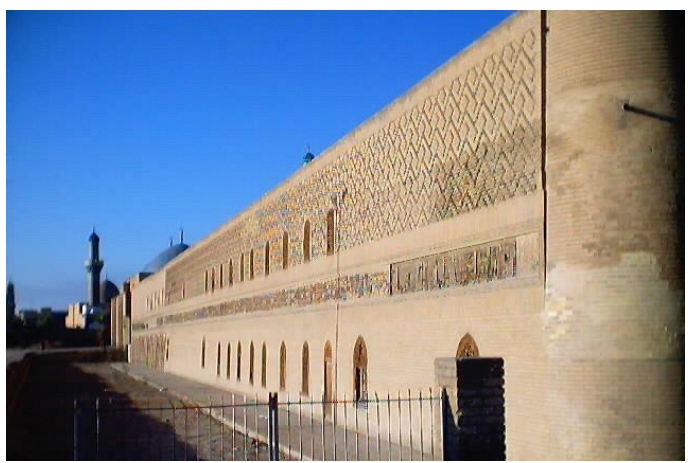

Figure (10): Mustansiriya river elevation

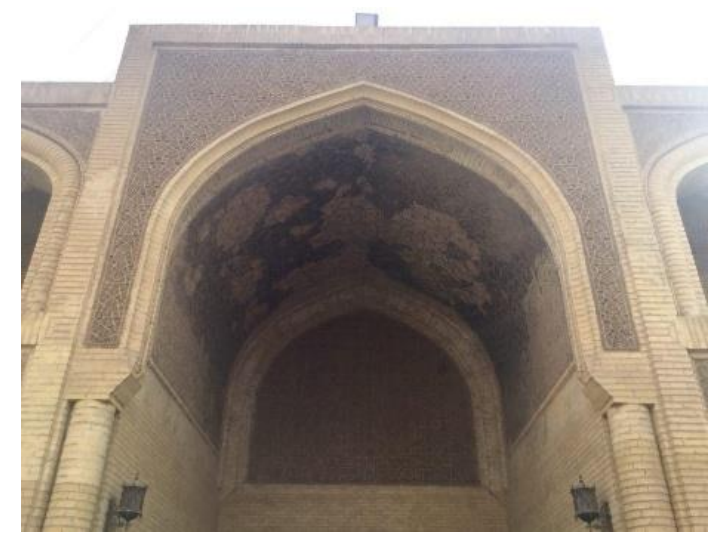

Figure (11): Mustansiriya fire effect (Authors, 2018)

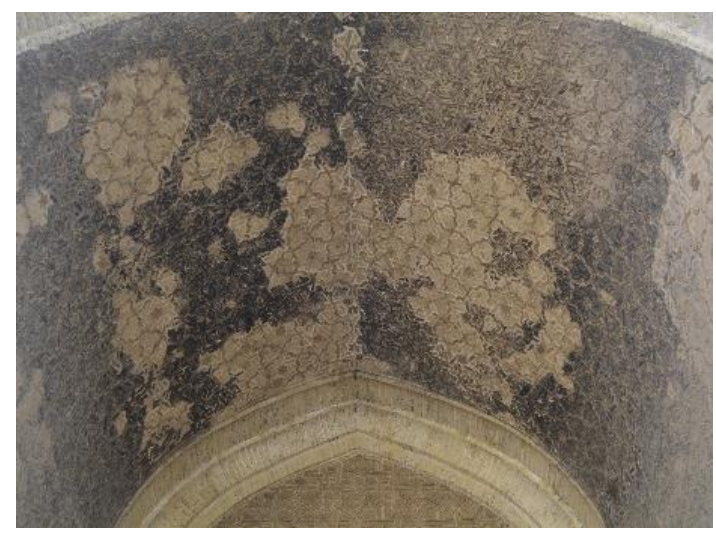

Figure (12): Mustansiriya fire effect (Authors, 2018)

\section{Conclusions:}

- Cultural Tourism can play a very important role in helping to preserve cultural heritage.

- The connection between heritage sites and tourism is dynamic. 
- The built heritage has many values, which plays a major role in supporting cultural tourism through:

- Attract local and foreign tourists with its (historical, cultural, artistic, architectural, religious) values.

- Sustainable source of income through its investment for tourism purposes commensurate with its (geographical, functional, structural, economic, social) values.

- The possibility to benefit from Mustansiriya Madrassa as a cultural destination through many activities including:

- Holding cultural, and touristic festivals annually, as well as international exhibitions of books and cultural and artistic activities, especially as it is close to $\mathrm{Al}$ Mutanabbi Street, which has an important cultural character.

- Tourism investment of the building by employing it as halls or museum of Islamic art, taking into account the carrying capacity of the building.

- Benefiting from its privileged location on the Tigris River by activating the river transport and also establishing tourist facilities required to serve the tourists.

- Activating the tourist guidance for the building and the surrounding area through the use of guiding signs and brochures, as well as guiding lectures that explain its cultural and historical role.

- The possibility of using technology to support tourist attractions such as the use of urban lighting and screens in historic areas.

\section{References:}

[1] Urry, J., "Tourist of Gaze: Leisure \& Travel in Contemporary Societies", Sage publications, (1990).

[2] Stebbins, R. S. A., "Cultural Tourism as Serious Leisure Annals of Tourism Research" 23(4) 948-950, (1996).

[3] ICOMOS Charter for Cultural Tourism, (1997), http://www.icomos.org/tourism/.

[4] Office of National Tourism, Fact Sheet No 10 Cultural Tourism, (1997).

www.Dcita.gov.au/swg/publicationsculttour.html.

[5] Arts Industry Tourism Council, Cultural Tourism Development in Victoria, (1997).

http://www.culturaldata.gov.au/publications/statistics wo rking.

[6] European Travel Commission, " City tourism \& culture: the European experience", World Tourism Organization (WTO), (2005).

[7] Atlas, "ATLAS Cultural Tourism Research Project", (2009).

http://www.tramresearch.com/atlas/presentation.htm
[8] Csapo, J., "The role and importance of cultural tourism in modern tourism industry. In Strategies for tourism industry", micro and macro perspectives, In Tech, (2012).

[9] Nowacki, M, " The Determinants of satisfaction of Tourist attractions 'visitors", 12-17, (2013).

[10] Gunn, C. A., "Attractions: First Power", $3^{\text {rd }}$ ed., Vacationscape, Taylor \& Francis, Washington DC, 24, (1997).

[11] Lew, A. A., "A framework of tourist attraction research Annals of tourism research", 14(4), 553-575, (1987).

[12] Gunn, C. A., "Tourism Planning", New York, Crane, Russak, ISBN 9780844817439,71,(1979).

[13] Thongmala, P., "Heritage sites as tourist attractions: a case study of Luang Prabang, Lao People's Democratic Republic, Doctoral dissertation, Lincoln University,19, (2010).

[14] Pearce, P. L., "Analysing tourist attractions" Journal of Tourism Studies", 2(1),46-55, (1991).

[15] Swarbrooke, J., "The Development \& Management of Visitor Attractions", 2nd, 5 Butterworth, (2002).

[16] Auberts, A., \& Csapó, J., "Unique Featuressof the Tourist Attractions in Hungary's Historical Small Cities, Settlement Dynamics and Its Spatial Impacts", 137-147, (2002).

[17] Timothy, D. J., \& Boyd, S. W, (2003), "Heritage tourism", Pearson Education.

[18] Siobhans, D., \& Yeoman, I., (2001), "Quality 5 Issues in Heritage Visitor Attractions",6, (2002).

[19] Howard, P., "Heritage management, interpretation, identity", A\&C Black,278,(2003).

[20] Icomos, G. A., (1999), "International Cultural Tourism Charter", Managing Tourism at 5 Places of Heritage Significance, 5-8,(2003). http://www. intemationa1. icom os. org/charters/tourism e. pd 1999-10.

[21] Hassan, Masra Shahir Bakr, "Preservation of Egyptian Architectural Heritage", Master Thesis, Faculty of Graduate Studies, Al Najah National University, Palestine, 4,(2005).

[22] Mahjoub, Yassers, (2010), "Architectural Heritage - Value and Preservation", article via the site: http://kenanaonline.com/users/YasserMahgoub/posts/13 $\underline{5427}$

[23] Strika, Vincenzo, Jabir Khalil, "The Islamic architecture of Baghdad", Napoli, 65-70,(1987).

[24] Bianca, Stefano, (2000), "Urban Form in The Arab World", Thames \& Hudson, 250.

[25] https://archnet.org/sites/3836

[26] Nashab, Hisham, "Muslim Educational institutions", Librairie du Liban, 22-45,(1989). 